\title{
The reproductive cycle of the European clam Ruditapes decussatus (L., 1758) in two Portuguese populations: Implications for management and aquaculture programs
}

\author{
Domitília Matias $^{\mathrm{a}, *, 1}$, Sandra Joaquim ${ }^{\mathrm{a}, 1}$, Ana Margarete Matias ${ }^{\mathrm{a}}$, Paula Moura ${ }^{\mathrm{a}}$ \\ Joana Teixeira de Sousa ${ }^{a, b}$, Paula Sobral ${ }^{c}$, Alexandra Leitão ${ }^{a}$
}

\author{
a Instituto Português do Mar e Atmosfera, Av. 5 de Outubro, 8700-305, Olhão, Portugal \\ b IFREMER, UMR 6539 Laboratoire des Sciences de l'Environnement Marin, Centre de Bretagne, 29280 \\ Plouzané, France \\ c IMAR-Instituto do Mar, Faculdade de Ciências e Tecnologia, Universidade Nova de Lisboa, P-2829 Caparica, \\ Portugal \\ ${ }^{1}$ Authors contributed equally to this paper. \\ *: Corresponding author : Domitília Matias, email address : dmatias@ipma.pt
}

\begin{abstract}
:
The reproductive cycle, as well as its nutrient storage and utilization, of two populations of Ruditapes decussatus from the main production areas of this species: Ria de Aveiro and Ria Formosa Lagoon (Portugal) were studied here over a 24 month period (May 2010-April 2012). The reproductive cycle of both populations of $R$. decussatus followed an annual cyclicality that comprised a ripe stage in spring followed by a spawning period that began in late spring and extended throughout summer until early autumn. This extended and continuous spawning period may be an advantageous strategy for this species by ensuring a continuous supply of gametes. Moreover, R. decussatus can adopt different reproductive strategies depending on the geographical origin. The results of both cycle of nutrients stored and nutrients utilization showed that clams of both populations present a high reproductive effort that almost depletes its energy reserves. Nevertheless, while Ria de Aveiro population retrieves them immediately after spawning, the same is not verified in clams from Ria Formosa Lagoon with their consequent debilitation. Also, based on the glycogen pattern it was possible to infer that the Ria Aveiro population is an opportunistic one, while the Ria Formosa Lagoon population exhibited an intermediate strategy. However, both populations could be considered as viable broodstock for intensive hatchery production of juveniles and the observed extended spawning periods presents interesting implications for the implementation of profitable aquaculture. Moreover, this species presented a great capacity for gonadal regeneration, which coupled with its high gonadal development rate would provide larvae during most of the year without extensive and expensive broodstock conditioning.
\end{abstract}

\section{Highlights}

Characterize the reproductive cycle of two Portuguese populations of R. decussatus Describe the patterns of nutrient stored and utilization during gametogenic cycle $>$ The species showed a long spawning period that is useful to aquaculture production. $-\mathrm{R}$ decussatus can adopt different reproductive strategies - Contribute to establish a successful hatchery-based production of R. decussatus

Keywords: European clam ; Ruditapes decussatus ; Reproductive cycle ; Portuguese populations ; Biochemical composition; Seasonal variations 


\section{Introduction}

The European clam Ruditapes decussatus is widely distributed along the coastal and estuarine areas of Europe and Northern Africa and represents an important resource income due to its high commercial value (Matias et al., 2009). $R$. decussatus is extensively produced and harvested in Portugal, where clam farming represents an important economical sector. This species is central to aquaculture's revenue, indeed in 2009 , the national annual production reported reached 2 metric tons (representing $27 \%$ of the total seafood cultured in Portugal) (DGPA, 2011). The main production areas of this species are the Ria de Aveiro $\left(40^{\circ} 42^{\prime} \mathrm{N}\right.$; $\left.08^{\circ} 40 \mathrm{~W}\right)$ and the Ria Formosa Lagoon $\left(37^{\circ} 01^{\prime} \mathrm{N} ; 07^{\circ} 49 \mathrm{~W}\right)$. In these production areas, clams are reared in plots in the intertidal zone. Clam farming involves seeding juveniles, collected from natural beds, into plots maintained in tidal flats and harvesting commercial size animals. The culture of $R$. decussatus in Ria Formosa Lagoon represents $90 \%$ of the national production and it is central to the socioeconomic framework. However, during the last two decades, the European clam production has suffered an important decrease due to several constraints, namely recruitment failures and excessive pressure on the capture of juveniles on natural banks and severe clam mortalities.

To address this situation, artificial spawning and larval rearing programs could provide an alternative source of spat.

To be able to establish and improve rearing programs for $R$. decussatus, a detailed knowledge of the species reproductive cycle and spawning periods is crucial. Effectively, the differences in gonadal cycles and conditioning optima in different populations have to be considered in hatchery operations (Devauchelle and Mingant, 1991; Lannan et al., 1980). There is also evidence that responses also vary between different geographical populations of the same species, as has been found for Mytilus galloprovincialis (Iglesias et al., 1996) and Argopecten purpuratus (Avendaño and Le Pennec, 1997). In the case of the European clam, in natural conditions, it has been 
reported that the ecotype decussatus living in different areas, even at the same latitude, could strongly differ in terms of their fecundity levels and biochemical compositions (Shaffee and Daoudi 1991; Trigui-El-Menif et al. 1995).

A relationship between the reproductive cycle and energy storage and utilization cycles has also already been reported by several authors for a wide variety of bivalves (e.g. Barber and Blake, 1981; Fernández-Castro and Vido-de-Mattio, 1987; Joaquim et al., 2011; Massapina et al., 1999; Pérez-Camacho et al., 2003; Ojea et al., 2004). The energy storage and utilization cycles translate into a seasonal pattern of biochemical composition that can vary according to species and geographical origin (Albentosa et al., 2007; Matias et al., 2009). Energy reserves are of considerable importance in reproduction and seasonal energy storage and utilization in bivalves are closely correlated to environmental conditions and the annual gametogenic cycles (e.g. Delgado et al., 2004; Holland, 1978; Ojea et al., 2004; Tlili et al., 2012). Food and temperature are the main factors that regulate the timing and rate of energy storage in bivalves (Joaquim et al., 2011). The effect of these variables is complex and depends specifically on acquisition and expenditure of energy (Pérez-Camacho et al., 2003). The most common model consists of an accumulation of energy during the periods where food is abundant. This energy is then used for the gametogenic synthesis and latter released during the spawning process (Albentosa et al., 2007). Proteins are mainly used in structural functions and represent an energy reserve in adult bivalves, particularly during gametogenesis and in situations of low glycogen levels, or severe energy equilibrium (Beninger and Lucas, 1984). Carbohydrates are assumed to constitute the most important bio-energy reserve in bivalve molluscs and, because of their hydro-solubility, are available for immediate use; being glycogen the main component for supplying energy demands (Fernández-Castro and Vito-de-Mattio, 1987) and reproductive cycle (e.g. Newell and Bayne 1980; Pazos et al., 2005). Lipids, due to their large calorific contributions per structural unit, account for a greater proportion of the energy reserves in bivalves than carbohydrates or proteins (Ojea et 
al., 2004). They play an important role in the gamete formation and are the main reserve of oocytes and bivalve larvae (Matias et al., 2009; 2011).

Although previous works have studied the natural reproduction of $R$. decussatus and its biochemical composition (Benninger and Lucas, 1984; Chryssanthakopoulou and kasparis, 2005; Hamida et al., 2004; Laruelle et al., 1994; Ojea et al., 2004; Rodríguez-Moscoso and Arnaiz, 1998; Serdar and Lök, 2009; Shafee and Daoudi, 1991; Trigui-El-Menif et al., 1995; Xie and Burnell, 1994), in Portuguese populations of this species only the gametogenic cycle has been determined in former studies of Vilela (1950) and Pacheco et al. (1989). Therefore, the present study aims to characterize the reproductive cycle of two populations of $R$. decussatus from the main production areas of this species: Ria de Aveiro and Ria Formosa Lagoon, and also include patterns of nutrient storage and utilization. This information would be essential for the establishment of a successful hatchery-based production.

\section{Materials and Methods}

\subsection{Sample collection}

Generally, samples of $R$. decussatus were hand-collected, monthly, at the same location in Ria de Aveiro and Ria Formosa Lagoon, during 24 months (May 2010 April 2012). Both areas are shallow water mesotidal lagoons with semidiurnal tidal regimes that constitute the major hydrodynamic forces (Dias et al., 2000; Nobre et al., 2005) (Figure 1). These lagoons, that distance $500 \mathrm{~km}$ from each other, have several channels and a large intertidal area covered by sand, muddy sand-flats, and salt marshes (Falcão and Vale, 1990; Picado et al., 2009). Ria Formosa has an extension of $55 \mathrm{~km}$ and a maximum width of $6 \mathrm{~km}$ (Newton and Mudge, 2003). The lagoon is separated from the Atlantic Ocean by several barrier islands and two peninsulas. The tidal range varies from $1.35 \mathrm{~m}$ on neap tides to $3 \mathrm{~m}$ on spring tides, and the coefficient 
152 of renovation of the lagoon is 3.2 in a spring tide and 1.0 in a neap tide. The freshwater

153 inputs are almost negligible and salinity remains close to 36 all year long (Águas, 1986;

154 Falcão and Vale, 1990). The Ria de Aveiro is $45 \mathrm{~km}$ long and $10 \mathrm{~km}$ wide, being 155 connected to the Atlantic Ocean by only a narrow channel (Picado et al., 2009), and 156 the tidal amplitude is $0.6 \mathrm{~m}$ in neap tides and $3.2 \mathrm{~m}$ in spring tides (Dias et al., 2000).

157 This lagoon has an important freshwater input coming from the Vouga and the Antuã 158 rivers (Dias et al., 2000; Moreira et al., 1993) and salinity ranged between 31 and 36. 159 These two ecosystems are currently used for clam production and fish aquaculture 160 ponds.

161 Monthly data on sea surface temperature (SST) and chlorophyll during the study period were derived from satellite remote sensing data, collected from the Giovanni online data system (MODIS-Aqua $4 \mathrm{~km}$, monthly processed data, available at http://disc.sci.gsfc.nasa.gov/giovanni/overview/index.html), developed and maintained by the NASA Goddard Environmental Sciences Data and Information Services Center GESDISC (Acker and Leptoukh, 2007).

\subsection{Laboratory analysis}

In the laboratory, clams were placed in $0.45 \mu \mathrm{m}$-filtered seawater at $20{ }^{\circ} \mathrm{C}$ for $24 \mathrm{~h}$ to purge their stomachs before histological, condition index and biochemical analyses.

\subsubsection{Histology}

Ten individuals of each sex from each monthly sample and each population were examined histologically to determine the gametogenic stages in both sexes. The visceral mass was separated from siphons and gills and fixed in Davison solution for 48 h, then transferred to $70 \%$ ethyl alcohol $(\mathrm{ETOH})$ for storage. Tissues from these 
samples were dehydrated with serial dilutions of alcohol and embedded in paraffin.

181 Thick sections $(6-8 \mu \mathrm{m})$ were cut on a microtome and stained with haematoxylin and eosin. The histologically prepared slides were examined using a microscope at $40 x$ magnification and each specimen was assigned to a stage which represented the gonadal state. Clam reproductive maturity was categorized into six stages using a scale development based on Delgado and Pérez-Camacho (2005) (Table 1). When more than one developmental stage occurred simultaneously within a single individual, the assignment of a stage criteria decision was based upon the condition of the majority of the section.

A mean gonadal index (GI) was calculated using the method proposed by Seed partially spawned (2); spent (1).

The GI ranged from 0 (all individuals in the sample are in rest stage) to 5 (all individuals are in ripe stage).

\subsubsection{Condition index} from each population, were determined after oven drying at $80{ }^{\circ} \mathrm{C}$ for $24 \mathrm{~h}$. Meat samples were then ashed at $450{ }^{\circ} \mathrm{C}$ in a muffle furnace, ash weight determined, and organic matter weight calculated as the ash free dry meat weight (AFDW). The condition index $(\mathrm{Cl})$ was calculated according to Walne and Mann (1975): [ash free dry weight (AFDW) of meat $(\mathrm{g}) / \mathrm{dry}$ shell weight $(\mathrm{g})]^{\star} 100$. 

frozen and stored at $-20^{\circ} \mathrm{C}$ for biochemical analyses. For each specimen, protein was determined using the modified Lowry method (Shakir et al., 1994), glycogen content was determined from dried $\left(80^{\circ} \mathrm{C}\right.$ for $24 \mathrm{~h}$ ) homogenate using the anthrone reagent

212 (Viles and Silverman, 1949) and total lipids were extracted from fresh homogenized 213 material in chloroform/methanol (Folch et al., 1957) and estimated 214 spectrophotometrically after charring with concentrated sulphuric acid (Marsh and Weinstein, 1966). Duplicate determinations were performed in all cases and values are expressed as a percentage of AFDW. Caloric content of proteins, lipids and carbohydrates in tissues was calculated using the factors $17.9 \mathrm{KJ} \mathrm{g}^{-1}$ (Beukema and De Bruin, 1979), $33 \mathrm{KJ} \mathrm{g}^{-1}$ (Beninger and Lucas, 1984) and $17.2 \mathrm{KJ} \mathrm{g}^{-1}$ (Paine, 1971), respectively.

Seasonal variations in condition index, biochemical composition and histological parameters were analyzed by one-way ANOVA or Kruskal-Wallis ANOVA on ranks whenever the assumptions of analysis of variance (ANOVA) failed. Percentage data were arcsine transformed to normalize variance (Sokal and Rohlf, 1981). Multiple pairwise comparisons were performed using the post-hoc parametric Tukey test or the non-parametric Dunn's test in order to detect significant differences between monthly consecutive samples. The Pearson correlation coefficient was used to determine the degree of association between parameters. Results were considered significant at $P<0.05$. The statistical analyses were performed using the SIGMASTAT 3.11 statistical package.

\section{Results}




\subsection{Temperature and chlorophyll}

The evolution of the monthly SST and chlorophyll during the experimental period in Ria de Aveiro and Ria Formosa Lagoon are presented in Figure 2. Ria de Aveiro presented lower temperature values than Ria Formosa Lagoon (around less $\left.2.95 \pm 1.31^{\circ} \mathrm{C}\right)$. A seasonal cycle in SST was observed in the two geographical locations studied, and the monthly means ranged between $19.49^{\circ} \mathrm{C}$ in September 2010 and $12.99{ }^{\circ} \mathrm{C}$ in February 2012 for Ria de Aveiro and $24.01^{\circ} \mathrm{C}$ in August 2010 and $15.03^{\circ} \mathrm{C}$ in February 2012 in Ria Formosa Lagoon. The evolution of the chlorophyll during the experimental period showed seasonal variations in geographical locations with several phytoplanktonic blooms in spring for Ria Formosa Lagoon and in spring/summer and autumn in Ria de Aveiro. Ria Formosa Lagoon presented lower values than Ria de Aveiro (around less $3.49 \pm 3.37 \mathrm{mg} \mathrm{m}^{-3}$ ) and the average of chlorophyll was $4.12 \pm 3.19$ $\mathrm{mg} \mathrm{m}^{-3}$ and $0.63 \pm 0.60 \mathrm{mg} \mathrm{m}^{-3}$ for Ria de Aveiro and Ria Formosa Lagoon, respectively.

\subsection{Gametogenic cycle} sexes showed synchronism in gonadal development. The reproductive cycle of $R$. decussatus was characterized by a seasonal pattern in both populations (Figure 3), however, no significant correlations were found between SST and GI and in chlorophyll and $\mathrm{Gl}$ in both populations (Table 2). The onset of the gametogenic cycle occurred in February in 2011 for males and females of both populations, in March in 2012 for males and females of Ria de Aveiro population and in April and March in 2012 for males and females of Ria Formosa Lagoon population, respectively. Despite the fact that no correlations were observed between SST and GI and chlorophyll and GI in both populations, the onset of the gametogenic cycle coincided with the increase of SST 
and with phytoplanktonic blooms. The development of gametes intensified quickly during the following month. The two populations reached its peak of reproductive effort between May and June, represented by the highest values of GI (Ria de Aveiro: females=4.4 in May and males $=3.5$ in June; Ria Formosa Lagoon: females=4.2 in May and males=3 in June) (Figure 4). Spawning began in late spring for both populations; in 2010, generally in June (except for males of Ria Formosa Lagoon population that began in May) and in March and May 2011 for Ria Formosa Lagoon and Ria Aveiro populations, respectively. Spawning of $R$. decussatus intensified during summer as SST increased, and continued until early autumn in both populations. Nevertheless, during this period and in spite of the seasonal pattern, $R$. decussatus did not show a continuous gonad development, after spawning clams did not progress to an inactive stage. Indeed, in the microscopic examinations of the gonadal tissues, all clams showed simultaneous spawning and recovery of the gonad. So, we considered this stage of the reproductive cycle of $R$. decussatus as partially-spawned (stage $\mathrm{V}-$ Table 1).This phenomenon occurred in all studied years and for both males and females of the two populations. In October the majority of clams had already spawned and was inactive and remained in this stage during approximately six months (which coincided with the decrease of SST and chlorophyll) until the next onset of gametogenesis. The gonadal index followed the same pattern as the gonadal development; no significant differences in $\mathrm{GI}$ were found between populations or between sexes (ANOVA, $P>0.05$ ).

\subsection{Condition index}

Condition index exhibited statistically significant differences between populations ( $\mathrm{K}-\mathrm{W} ., \mathrm{H}=7.683$, d.f.=1, $\mathrm{P}=0.006$ ), especially when clams were in the inactive stage, between September and October 2010 and August and November 2011. These differences between populations were also relevant between May and July 2010 (ANOVA, F=26.61, d.f.=7, $\mathrm{P}<0.001$ ). In Ria de Aveiro population, $\mathrm{Cl}$ was 
positively correlated with SST (Pearson, $r=0.74, \mathrm{P}<0.001$ ), however no correlation was observed between these two parameters in Ria Formosa Lagoon. No correlations were observed between $\mathrm{Cl}$ and chlorophyll for both populations. In 2010, the $\mathrm{Cl}$ of the Ria de Aveiro population generally trended upwards until September following SST increase (with an exception in July, with a GI contribution) and phytoplanktonic bloom (August), when the highest value $(11.96 \pm 1.38)$ of the sampling period was registered (Figure 5), coinciding with the end of the reproductive cycle of the species. In the following month the $\mathrm{Cl}$ decreased coinciding with the end of spawning. However, no relationship was observed between $\mathrm{Gl}$ and $\mathrm{Cl}$ for the Ria de Aveiro population (Table 2). In the Ria Formosa Lagoon population the $\mathrm{Cl}$ in 2010 remained high and relatively stable in the first three months of sampling when the majority of clams were in late activity and ripe stage, decreasing sharply from July with the evolution of spawning and consequent rest period. This decline was also coincident with the lowest values of chlorophyll. The lowest $\mathrm{Cl}$ value $(4.00 \pm 0.80)$ of the sampling period was registered in October 2010 in the Ria Formosa Lagoon population. In 2011, Ria de Aveiro population showed two peaks in the $\mathrm{Cl}$, the first one in May and another one in October. In contrast, Ria Formosa Lagoon population only showed one peak in May/June which correspond to the maximum $\mathrm{Gl}$ value of this year achieved with the contribution of the ripe stage of (Figure 4).

\subsection{Biochemical composition} total lipids and glycogen (Table 3). The highest protein content values were recorded in 
May $2010\left(531.7 \pm 180.0 \mu \mathrm{g} \mathrm{mg}{ }^{-1}\right.$ AFDW) and October $2010\left(520.8 \pm 123.5 \mu \mathrm{gg}^{-1}\right.$ AFDW) and the lowest in September $2010\left(128.3 \pm 32.6 \mu \mathrm{g} \mathrm{mg}^{-1}\right.$ AFDW) and February $2011\left(142.2 \pm 23.6 \mu \mathrm{g} \mathrm{mg}{ }^{-1}\right.$ AFDW) for Ria de Aveiro and Ria Formosa Lagoon populations, respectively. Significant differences were found between populations (ANOVA, $F=4.04$, d.f. $=1, P=0.045$ ), especially in July, August and September 2010 and February 2011. Glycogen content between clams of the two populations showed significant differences (ANOVA, d.f.=1, $F=58.89 P<0.001$ ), especially when clams were inactive in terms of reproduction (Period of sexual rest). In this period, the reserves of glycogen were considerably higher in the Ria de Aveiro clams than in the ones from Ria Formosa. This content generally decreased in both populations until August 2010. In September 2010, the highest $\left(53.7 \pm 22.9 \mu \mathrm{g} \mathrm{mg}^{-1}\right.$ AFDW $)$ and the lowest $(7.2 \pm 2.4 \mu \mathrm{g}$ populations, respectively. After that, the glycogen contents showed opposing trends until February 2011, when the values of the two populations approached. The lowest glycogen values of clams from Ria de Aveiro $\left(9.1 \pm 5.8 \mu \mathrm{g} \mathrm{mg}^{-1}\right.$ AFDW) were observed in June 2011. Glycogen was positively correlated with $\mathrm{Cl}$ (Pearson, $\mathrm{r}=0.79, \mathrm{P}<0.001$ ) and $\mathrm{GI}$ (Pearson, $r=0.60, \mathrm{P}=0.01$ ) in Ria Formosa Lagoon population (Table 2). The lowest (Ria de Aveiro: $35.0 \pm 9.8 \mu \mathrm{g} \mathrm{mg}^{-1}$ AFDW; Ria Formosa: $27.2 \pm 7.3 \mu \mathrm{g} \mathrm{mg}^{-1}$ AFDW) and the highest (Ria de Aveiro: 118.1 $\pm 20.5 \mu \mathrm{g} \mathrm{mg}^{-1}$ AFDW; Ria Formosa: 112.1 $\pm 15.1 \mathrm{\mu g} \mathrm{mg}^{-1}$ AFDW) total lipid values were reached in October 2010 and June 2010 and April 2012 and July 2011, respectively. No significant differences were found between populations for total lipids (ANOVA, $\mathrm{P}>0.05$ ). Total lipids of clams from Ria de Aveiro population were negatively correlated with proteins (Pearson, $r=-0.52, P<0.039$ ). Proteins contributed the most to the total energy content (Ria de Aveiro: Pearson, $r=0.87, \quad P<0.001$; Ria Formosa Lagoon: Pearson, $r=0.91, P<0.001$ ) (Table 2). Significant differences were observed between populations for total energy (K-W., $H=3.899$, d.f. $=1, P<0.05$ ), especially in July and August 2010 and February 2011 and 2012. 


\section{Discussion}

The reproductive activity of bivalves, which includes a sequence of events from gametogenesis to spawning, is controlled by the interaction between endogenous

352 (Enríquez-Díaz et al., 2009; Normand et al., 2008) and exogenous factors, mainly food availability and temperature. Moreover, temperature is closely linked to the geographical locations affecting indirectly the availability of food and/or consequently the timing and duration of the reproductive cycle and number of spawning per year. For R. decussatus a different number of annual spawns has been described within Europe (da Costa et al., 2012).

Seawater temperature and chlorophyll patterns, in this study, were common for both studied lagoons and were typical from temperate climates. In both lagoons, temperature increased during spring, stabilized in summer, decreased during autumn and remained low in winter. Also both lagoons are characterized with several phytoplanktonic blooms in spring/summer. Nevertheless, Ria de Aveiro was distinguished by relatively lower SST values and higher chlorophyll values than Ria Formosa Lagoon.

Despite no significant correlation was found between SST and the gonadal index, the sequence of gametogenic stages showed that the reproductive cycle of these two populations of $R$. decussatus follow a seasonal cycle, as has been previously reported for this and several other bivalve species (e.g. Albentosa et al., 2007; Gabbott, 1976; Xie and Burnell 1994). The reproductive cycle of $R$. decussatus comprised a ripe stage in spring followed by spawning that began in late spring and extended during summer until early autumn in both populations. A similar reproductive cycle was described in the studies by Breber (1980) and Ojea et al. (2004) for a population of $R$. decussatus from Galicia (Spain) and from Venice (Italy), respectively. 
374 However, other authors have shown the occurrence of two major periods of spawning,

375 in spring and then in summer or early autumn in different populations of this species

376 (Morocco - Shafee and Daoudi, 1991; France - Borsa and Millet, 1992; Lauruelle et al.,

377 1994; Greece - Chryssanthakopoulou and Kaspiris, 2005) including in populations

378 from the Ria Formosa Lagoon (Pacheco et al., 1989; Vilela, 1950). The differences

379 observed between studies have been frequently associated to the influence of the

380 geographical location and consequently by the inherent environmental factors (vide da

381 Costa et al., 2012). Nevertheless, in our study, no significant differences were

382 observed between the reproductive cycles of the two geographically distinct

383 populations studied.

384 Beside the fact that the seasonal pattern presented a spawning period welldefined in time, clams of the two studied populations exhibited an advantageous reproductive strategy for the species ensuring a consistent supply of gametes during the whole spawning period. Indeed, histological analyses showed simultaneously gonias, maturing gametocytes and variable proportions of fully matured gametes in the same individual, both in males and females. This high capacity for gonadal regeneration had also been previously observed by our team in Venerupis senegalensis from Ria de Aveiro (Joaquim et al., 2011). Nevertheless, and despite the intra-individual asynchrony, the maintenance of a synchronized gonadal development observed between males and females ensures the reproductive success of the species since sperm and oocytes will be expelled into the water column simultaneously during the spawning period, augmenting the probability of fertilization. This synchronism had previously been reported by Laruelle et al. (1994) and Ojea et al. (2004) for this species. Both populations showed a long reproductive rest phase that was extended by associate with the rise of SST and chlorophyll in late winter/early spring for both populations and the development of gametes intensified quickly until the attainment of 
402 the ripe stage late spring. These results were generally consistent with the previous 403 findings by Chryssanthakopoulou and Kaspiris (2005), Shafee and Daoudi (1991) and Vilela (1950 in other populations of this species, although, as previously mentioned, these authors reported another onset of gametogenesis in July/August.

Condition index is generally considered to reflect the reproductive activity of bivalves (Fernández-Castro and Vido de Mattio, 1987; Massapina et al., 1999; Ojea et al., 2004). The positive correlation between these two parameters has been observed in several bivalve species from the Portuguese coast (e.g. Gaspar and Monteiro, 1988; Joaquim et al., 2011; Moura et al., 2008). In this study the $\mathrm{Cl}$ exhibited significant differences between populations, especially when clams were in the inactive stage (Period of sexual rest), between September and October 2010 and August and November 2011. Although, in the general no significant correlations between $\mathrm{Cl}$ and chlorophyll were observed in both areas, this fact seems to be associated with the greater food availability in the Ria de Aveiro comparatively with the Ria Formosa lagoon. Despite the fact that a positive correlation between $\mathrm{Cl}$ and SST was observed in Ria de Aveiro, the $\mathrm{Cl}$ did not reflect the reproductive cycle of this population, since no significant relationship was found between these parameters. In 2010 , the $\mathrm{Cl}$ of this population followed the SST increase and generally trended upwards until September. After that, the $\mathrm{Cl}$ decreased, coinciding with the end of the spawning period and SST decrease. In 2011, Ria de Aveiro population showed two peaks in $\mathrm{Cl}$ that accompanying the SST trend; the first one in May when the majority of the clams were ripe and another one in October, however, in this last one the rest stage was the more frequent stage observed. In contrast, no significant positive correlation was found between $\mathrm{Cl}$ and SST in the Ria Formosa Lagoon population, however, in this population, the $\mathrm{Cl}$ was positively correlated with the $\mathrm{GI}$. In $2010, \mathrm{Cl}$ remained high when the majority of clams were in advanced gametogenesis and ripe stages, decreasing sharply with partial spawning and consequent rest period. In 2011, Ria Formosa Lagoon population only showed one peak of $\mathrm{Cl}$ in May/June which 
corresponded to the maximum GI value of that year achieved with the contribution of the ripe stage of most of the clams. The reduction of the Ria Formosa Lagoon $\mathrm{Cl}$ coincided with the rest period of clams.

In previous studies it has been reported that the $\mathrm{Cl}$ is highly influenced by the energy storage and exploitation strategy of bivalve species (Delgado and PérezCamacho, 2005; Joaquim et al., 2008; 2011). Clams from Ria de Aveiro seem to have the ability to recover quickly the reserves after spawning when the SST and food availability (chlorophyll) are still high. These reserves seem to be harnessed to maintain their physiological state during winter. The same was not verified in the Ria Formosa Lagoon population. Clams lost their reserves with the intensification of the spawning event and were only able to recover them, slowly during winter, and more rapidly with the next SST increase. This fact is probably associated to the low levels of chlorophyll observed in Ria Formosa Lagoon, especially in the Summer/Autumn months. The major energetic effort suffered by clams during spawning leads then to their debility which might be at the origin of episodes of severe mortalities in the Ria Formosa Lagoon population after the reproductive period. Several factors can contribute to this difference in the energy storage and exploitation strategy between the two studied populations. da Costa et al. (2012) reports that another environmental variable that affects the energetic strategy of bivalves is immersion time. In our study, the subtidal clams from Ria de Aveiro showed higher $\mathrm{Cl}$ values than the intertidal clams of Ria Formosa Lagoon during the rest period.

Several studies on bivalves have shown that sexual maturity is related to energy supply from previously stored reserves or the ingestion of available food and consequently is closely linked with the biochemical composition (Pérez-Camacho et al., 454 2003; Sastry, 1979). The reproductive cycle translates a seasonal pattern of 455 biochemical composition that can vary among populations and species (Albentosa et 456 al., 2007). The relative amounts of proteins (Ria de Aveiro - 128 to $532 \mu \mathrm{gg}^{-1}$ AFDW; 457 Ria Formosa Lagoon - 142 to $520 \mathrm{\mu g} \mathrm{mg}^{-1}$ AFDW), glycogen (Ria de Aveiro - 9 to 54 
$458 \mu \mathrm{g} \mathrm{mg}{ }^{-1}$ AFDW; Ria Formosa Lagoon - 7 to $45 \mu \mathrm{g} \mathrm{mg}^{-1}$ AFDW) measured in $R$. 459 decussatus were lower, in term of the proportions, to those previously described in the 460 literature for this species, however the amount of total lipids (Ria de Aveiro - 35 to 118 $461 \mu \mathrm{g} \mathrm{mg}{ }^{-1}$ AFDW; Ria Formosa Lagoon - 27 to $112 \mu \mathrm{g} \mathrm{mg}^{-1}$ AFDW) was higher (e.g. 462 Aníbal et al., 2011; Ojea et al., 2004).

Several authors have suggested that, in bivalves, somatic proteins are used as an energy reserve in situations of nutritional stress and energy imbalance or during gonadal maturation (e.g.Gabbott and Bayne, 1973; Liu et al., 2008). Moreover, it has also been suggested that some species use proteins as a source of energy maintenance when carbohydrate reserves have already been depleted (Albentosa et al., 2007; da Costa et al., 2012; Joaquim et al., 2011). In this study, in 2010 the sudden decrease in protein content in both populations after spawning, when glycogen reserves were also depleted, suggests that proteins were indeed used for maintenance of the species; however, the same was not true for 2011 where no regular seasonal trend was observed. In this study, no correlation was found between proteins and glycogen and $\mathrm{Gl}$ and significant differences were found between both populations protein content.

Glycogen is the main energy reserve in adult bivalves. In $R$. decussatus it can be an energy source for growth and at the same time stored in specific cells as an process forced a striking consumption of the glycogen in both populations, after that, higher and lower values were recorded for Ria de Aveiro and Ria Formosa Lagoon, respectively. During the rest period the glycogen content of both populations also showed opposite trends. Some bivalve species store glycogen when food is abundant and gametogenesis takes place when there is low food availability, thus allowing the first spawning release when seawater temperature increases (conservative strategy), 
and there are others species in which the gamete production occurs from spring onwards, coupled with the first phytoplanktonic blooms (opportunistic strategy) (da Costa et al., 2012). Ojea et al. (2004) and Urrutia et al. (1999) in studies with Spanish populations (Galician and Basque Country) have considered $R$. decussatus as a conservative species however Aníbal et al. (2011) concluded that $R$. decussatus from the Ria Formosa Lagoon exhibited an intermediate strategy. Our results corroborate this last thesis. In fact, although glycogen was positively correlated with GI, which is typical from an opportunistic species, the Ria Formosa Lagoon population stored this reserve during the winter and after that both stored and recently assimilated glycogen content was used for gametogenesis. In Ria de Aveiro population, despite the fact that clams have used the after spawning stored glycogen reserves during autumn and winter, which is typical from a conservative species, gametogenesis was not started and no significant correlations were found between glycogen content and Gl. The onset of gamete production was only verified in early spring, associated with the first phytoplanktonic bloom, which is typical of an opportunistic strategy. These differences in the reproductive strategy between geographically distinct populations of the same species were also reported by Cerviño-Otero (2011) and da Costa et al. (2012). As previously mentioned the two populations also differed in the amount of glycogen stored, especially when clams were inactive in terms of reproduction. In fact, reserves were stored as glycogen soon after the spawning period in Ria de Aveiro population which is coincident with the phytoplanktonic bloom observed in autumn, however the same was not verified in the Ria Formosa Lagoon population. Consequently, in rest stage, the reserves of glycogen were considerably higher in Ria de Aveiro clams then in Ria Formosa Lagoon one's, corroborating the $\mathrm{Cl}$ results. A significant positive correlation between glycogen content and $\mathrm{Cl}$ was found in Ria Formosa Lagoon population. Several authors (e.g. Beninger and Lucas, 1984; Mouneyrac et al., 2008; Ojea et al., 2004) have reported that lipid seasonal variations are inversely related with 
514 glycogen, due to the conversion of glycogen to lipids, biosynthesized during the

515 formation of gametes (Gabbott, 1975). In the present study, total lipids increased with

516 the onset of gametogenesis. After that and during the reproductive period, an erratic

517 variation of total lipids occurred in both populations that could be related with the

518 successive gamete production and release, typical of a partial spawning species. Total

519 lipids also peaked immediately after spawning. These results suggest that, more than a

520 consequence of gametogenesis, the total lipids content also reflects the energy

521 accumulation process and its consumption during bivalve somatic development, as has

522 been previously reported by other authors (Albentosa et al., 2007; Joaquim et al., 2008,

523 2011).

524 The negative correlation found between proteins and total lipids in clams from

525 Ria de Aveiro population reinforce the idea that proteins can be used as an energy

526 reserve in stress situations. Moreover, in our study, protein was the constituent that

527 most contributed to the total energy of $R$. decussatus.

528 In conclusion, the results of this study show that $R$. decussatus has a partial 529 spawning period, during which occurs successive and simultaneous production of 530 gametes and spawning. Moreover, it was also demonstrated that this species can 531 adopt different energy storage depending on the geographic origin. Clams of both 532 populations show a high reproductive effort that almost depletes its energy reserves; 533 however, while the Ria de Aveiro population retrieves them immediately after 534 spawning, the same is not verified in clams from the Ria Formosa Lagoon which leads 535 to their consequent debilitation, probably due to the different levels of food availability 536 in the two lagoons.

537 Both populations presented however viable broodstock for intensive hatchery 538 production of juveniles and the extended spawning period of both $R$. decussatus 539 populations has interesting implications for the implementation of profitable 540 aquaculture. Moreover, the high gonadal regeneration capacity presented by this 541 species coupled with its high gonadal development rate would provide larvae during 
542 most of the year without the need of performing extensive and expensive broodstock 543 conditioning.

544 We believe that the results of our study could then be useful to $R$. decussatus 545 hatchery production programs. These programs should take into consideration that: the 546 extended natural spawning period implies that manipulation of broodstock in terms of 547 conditioning, which should be initiated in early winter, would be relatively easy; the 548 great capacity for gonadal regeneration, coupled with its high gonadal development 549 rate would provide larvae over much of the year without extensive and expensive 550 broodstock conditioning; the Ria de Aveiro population are the most suitable broodstock 551 for hatchery production due to their reproductive strategy. Moreover the global 552 information obtained in this study on the gametogenic cycle and consequent energy storage will also allow the determination of the optimal reproductive time for artificial spawning induction for aquaculture production of this species.

Acknowledgments

557

558 The authors are grateful to João Curdia and all the staff of the Molluscan Aquaculture 559 Experimental Station of IPMA in Tavira for their assistance. We also acknowledge Luz Abreu for her assistance with biochemical analysis and J. White for her help in editing the English language of the manuscript. This work was supported by the projects FP7KBBE-2009-3 REPROSEED ("REsearch to improve PROduction of SEED of established and emerging bivalve species in European hatcheries"), MARINAQUA -

564 PROMAR and "Ciência 2007 Program". 
Acker, J., Leptoukh, G., 2007. Online analysis enhances use of NASA Earth science data. Eos, Transactions, American Geophysical Union 88: 14.

Águas, M.P.N., 1986. Simulação da circulação hidrodinâmica na Ria Formosa. In Os sistemas Lagunares do Algarve. Seminário comemorativo do dia mundial do ambiente. Universidade do Algarve, Faro, 5-7 Junho 1985:78-90. (In portuguese).

Albentosa, M., Fernández-Reiriz, M.J., Labarta, U., Pérez-Camacho, A., 2007. Response of two species of clams, Ruditapes decussatus and Venerupis pullastra, to starvation: Physiological and biochemical parameters. Comp. Biochem. Physiol., Part B: Biochem. Mol. Biol. 146, 241-249.

Aníbal, J., Esteves, E., Rocha, C., 2011. Seasonal variations in gross biochemical composition, percent edibility, and condition index of the clam Ruditapes decussatus cultivated in the Ria Formosa (South Portugal). J. Shellfish Res. 30(1), 17-23.

Avendaño, M., Le Pennec, M., 1997. Intraspecific variation in gametogenesis in two populations of the Chilean molluscan bivalve, Argopecten purpuratus (Lamarck). Aquacul. Res. 28, 175-182.

Barber, B.J., Blake, N.J., 1981. Energy storage and utilization in relation to gametogenesis in Argopecten irradians concentricus (Say). J. Exp. Mar. Biol. Ecol. 52, 121-134.

Beninger, P.G., Lucas, A., 1984. Seasonal variation in condition, reproductive activity and gross biochemical composition of two species of adult clam reared in a common habitat: Tapes decussatus L. (Jeffreys) and Tapes philippinarum (Adam and Reeve). J. Exp. Mar. Biol. Ecol. 79, 19-37.

Beukema, J.J., De Bruin, W., 1979. Calorific values of the soft parts of the tellinid bivalve Macoma balthica (L.) as determined by two methods. J. Exp. Mar. Biol. Ecol. 37, 19-30. 
Borsa, P., Millet, B., 1992. Recruitment of the clam Ruditapes decussatus in the Lagoon of Thau, mediterranean. Estuar. Coast. Shelf Sci. 35, 289-300.

Breber, P., 1980. Annual gonadal cycle in the carpet-shell clam Venerupis decussata in Venice Lagoon, Italy. Proceedings of the National Shellfishries Association 70, 31-35.

Cerviño-Otero, A., 2011. Ciclo reproductivo, cultivo en criadero y en el medio natural de la almeja babosa Venerupis pullastra (Montagu, 1803). Ph.D Thesis. University of Santiago de Compostela. 288 pp. (In Spanish)

Chryssanthakopoulou, V., Kaspiris, P., 2005. Reproductive cycle of the carpet shell clam Ruditapes decussatus (Linnaeus 1758) in Araxos lagoon (NW peloponnisos, Greece) and in Evinos estuary (South Aitoloakarnania, Greece). Fresen. Environ. Bull. 14 (11), 999-1005.

da Costa, F., Aranda-Burgos, J.A., Cerviño-Otero, A., Fernández-Pardo, A., Louzán, A., Nóvoa, S., Ojea, J., Martínez-Patiño, D., 2012. Clam reproduction. In: da Costa F. (ed) Clam Fisheries and Aquaculture. Centro de Cultivos Marinos de Ribadeo- CIMA, Muelle de Porcillán, Lugo, Spain.

Delgado, M., Pérez-Camacho, A., 2005. Histological study of the gonadal development of Ruditapes decussatus (L.) (Mollusca Bivalvia) and its relationship with available food. Sci. Mar.69(1), 87-97.

Delgado, M., Pérez-Camacho, A., Labarta, U., Fernández-Reiriz, M.J., 2004. The role of lipids in the gonadal development of the clam Ruditapes decussatus (L.). Aquaculture 241(1-4), 395-411.

Deslous-Paoli, J.M., Heral M., 1988. Biochemical composition and energy value of Crassostrea gigas (Thunberg) cultured in the Bay of Marennes-Oleron. Aquat. Living Res. 1, 239- 249.

Devauchelle, N., Mingant, C., 1991. Review of the reproductive physiology of the scallop, Pecten maximus, applicable to intensive aquaculture. Aquat. Living Res. 4, 41-51. 
DGPA, 2011. Recursos da Pesca. Série estatística, 2009. Direcção Geral das Pescas e Aquicultura (22 A-B), 181 p. Lisboa. (In portuguese).

Dias, J.M., Lopes, J.F., Dekeyser, I., 2000. Tidal propagation in Ria de Aveiro lagoon, Portugal. Phys. Chem. Earth, PT B 25, 369-374.

Enríquez-Díaz, M., Pouvreau, S., Chávez-Villalba, J., Le Pennec, M., 2009. Gametogenesis, reproductive investment, and spawning behavior of the Pacific giant oyster Crassostrea gigas: evidence of an environment-dependent strategy. Aquacul. Int. 17, 491-506.

Eversole, A.G., 2001. Reproduction in Mercenaria mercenaria. In: Knauer J., Castagna M. (eds.) Biology of the Hard Clam, Elsevier, Amsterdam, pp 221-260.

Eversole, A.G., Michener, W.K., Eldridge, P.J., 1980. Reproductive cycle of Mercenaria mercenaria in a South Carolina estuary. Proceed. Nat. Shellfish Ass. 70, 20-30.

Falcão, M., Vale, C., 2003. Nutrient dynamics in a coastal lagoon (Ria Formosa, Portugal): The importance of lagoon-sea water exchanges on the biological productivity. Sci. Mar. 29, 425-433.

Fernández-Castro, N., Vido-de-Mattio, N., 1987. Biochemical composition, condition index, and energy value of Ostrea puelchana (d'Orbigny): relationships with reproductive cycle. J. Exp. Mar. Biol. Ecol. 108, 113-126.

Folch, J., Lees, M., Sloane Stanley, G.H., 1957. A simple method for the isolation and purification of total lipids from animal tissue. J. Biol. Chem. 226, 497-509.

Gabbott, P.A., 1975. Storage cycles in marine bivalve molluscs: an hypothesis concerning the relation between glycogen and gametogenesis. In: Barnes $\mathrm{H}$. (ed.) Proceedings of the Ninth European Marine Biology Symposium, Aberdeen University Press, Aberdeen, Scotland. pp 191-211.

Gabbott, P.A., 1976. Energy metabolism. In: Bayne B.L. (ed) Marine mussels: their ecology and physiology. International Biological Programme. Vol 10. Cambridge University Press, London, pp 293-355. 
650 Gabbott, P.A., Bayne, B.L., 1973. Biochemical effects of temperature and nutritive

651

652

653

654

655

656

657

658

659

660

661

662

663

664

665

666

667

668

669

670

671

672

673

674

675 stress on Mytilus edulis L. J. Mar. Biol. Assoc. U. K. 53, 269-286.

Gaspar, M.B., Monteiro, C.C., 1998. Reproductive cycles of the razor clam Ensis siliqua and the clam Venus striatula of Vilamoura, southern Portugal. J. Mar. Biol. Assoc. U. K. 78, 1247-1258.

Holland, D.L., 1978. Lipid reserves and energy metabolism in the larvae of benthic marine invertebrates. In: Malins, P.L., Sargent, J.R. (eds.), Biochemical and Biophysical Perspectives in Marine Biology. Academic Press, London, pp. 85123.

Iglesias, J.I.P., Camacho, C., Navarro, E., Labarta, U., Beiras, R., Hawkins, A.J.S., Widdows, J., 1996. Microgeographic variability in feeding, absorption and condition of mussels (Mytilus galloprovincialis Lmk): A transplant experiment. J. Shellfish Res. 15(3), 673-680.

Joaquim, S., Matias, D., Lopes, B., Arnold, W.S., Gaspar, M.B., 2008. The reproductive cycle of white clam Spisula solida (L.) (Mollusca: Bivalvia): Implications for aquaculture and wild stock management. Aquaculture 281, 43-48.

Joaquim S., Matias D., Ramos M., Moura P., Arnold W., Chícharo L., Gaspar M., 2011. Seasonal variations in reproductive activity and biochemical composition of the pullet carpet shell Venerupis senegalensis (Gremlin, 1791) from Ria de Aveiro (northwestern coast of Portugal). Sci. Mar. 75(2), 217-226.

Lannan, J.E., Robinson, A., Breese, W.P., 1980. Broodstock management of Crassostrea gigas. II. Broodstock conditioning to maximise larval survival. Aquaculture 21, 337-345.

Laruelle, F., Guillou, J., Paulet, Y.M., 1994. Reproductive pattern of clams, Ruditapes decussatus and $R$. phillippinarum on intertidal flats in Brittany. J. Mar. Biol. Ass. U.K. 74(2), 351-366. 
676 Liu, W., Li Q., Yuan, Y., Zhang, S., 2008. Seasonal variations on reproductive activity and biochemical composition of the cockle Fulvia mutica (Reeve) from the eastern coast of China. J. Shellfish Res. 27(2), 405-411.

Magnesen, T., Christophersen, G., 2008. Reproduction cycle and conditioning of translocated scallops (Pecten maximus) from five broodstock populations in Norway. Aquaculture 285, 109-116.

Marin, M.G., Moschino, V., Deppieri, M., Lucchetta, L., 2003. Variations in gross biochemical composition, energy value and condition index of Tapes philippinarum from the lagoon of Venice. Aquaculture 219, 859-871.

Marsh, J.B., Weinstein, D.B., 1966. Simple charring method for determination of lipids. J. Lipid Res 7, 574-576.

Massapina, C., Joaquim, S., Matias, D., Devauchelle, N., 1999. Oocyte and embryo 688 quality in Crassostrea gigas (Portuguese strain) during a spawning period in Algarve, South Portugal. Aquat. Living Res. 12, 327-333.

Matias D., Joaquim S., Leitão A., Massapina C., 2009. Effect of geographic origin, temperature and timing of broodstock collection on conditioning, spawning success and larval viability of Ruditapes decussatus (Linné, 1758). Aquacult. Int. $17,257-271$.

Matias, D., Joaquim S., Ramos, A., Sobral, P., Leitão, A., 2011. Biochemical compounds' dynamics during larval development of the carpet-shell clam Ruditapes decussatus (Linnaeus, 1758): effects of mono-specific diets and starvation. Helgoland Mar. Res. 65(3), 369-380.

Moreira, M.H., Queiroga, H., Machado, M.M., Cunha, M.R., 1993. Environmental gradients in a southern Europe estuarine system: Ria de Aveiro, Portugal: implications for soft bottom macrofauna colonization. Neth. J. Aquatic Ecol. 27, 465-482.

Mouneyrac, C., Linot, S., Amiard, J.C., Amiard-Triquet, C., Métais, I., Durou, C., Minier, C., Pellerin, J., 2008. Biological indices, energy reserves, steroid hormones and 
sexual maturity in the infaunal bivalve Scrobicularia plana from three sites differing by their level of contamination. Gen. Comp. Endocr. 157, 133-141.

706

707

708

709

710

711

712

713

714

715

716

717

718

719

720

721

722

Moura, P., Gaspar, M.B., Monteiro, C.C., 2008. Gametogenic cycle of the smooth clam Callista chione on the southwestern coast of Portugal. J. Mar. Biol. Ass. U.K. 88, 161-167.

Newell, R.I., Bayne, B.L., 1980. Seasonal changes in the physiology, reproductive condition and carbohydrate content of the cockle Cardium (=Cerastoderma) edule (Bivalve: Cardiidae). Mar. Biol. 56, 11 -19.

Newton, A., Mudge, S.M., 2003. Temperature and salinity regimes in a shallow, mesotidal lagoon, the Ria Formosa, Portugal. Estuar. Coast. Shelf Sci. 57, 7385.

Nobre, A.M., Ferreira, J.G., Newton, A., Simas, T., Icely, J.D., Neves, R., 2005. Management of coastal eutrophication: integration of field data, ecosystem-scale simulations and screening models. J. Mar. Sys. 56, 375-390.

Normand, J., Le Pennec, M., Boudry, P., 2008. Comparative histological study of gametogenesis in diploid and triploid Pacific oysters (Crassostrea gigas) reared in an estuarine farming site in France during the 2003 heatwave. Aquaculture 282: $124-129$.

O'Connor, W.A., Heasman, M.P., 1995. Spawning induction and fertilisation in the doughboy scallop Chlamys (Mimachlamys) asperrima. Aquaculture 136: 117-129.

Ojea, J., Pazos, A.J., Martínez, D., Novoa, S., Sánchez, J.L., Abad, M., 2004. Seasonal variation in weight and biochemical composition of the tissues of Ruditapes decussatus in relation to the gametogenic cycle. Aquaculture 238, 451-468.

Pacheco, L., Vieira, A., Ravasco, J., 1989. Crescimento e reprodução de Ruditapes decussatus na Ria Formosa (Sul de Portugal). Bentos 6,129-136. (In portuguese).

Paine, R.T., 1971. The measurement and application of the calorie to ecological problems. Annu. Rev. Ecol. Syst. 2, 145-164. 
Pazos, A.J., Silva, A., Vázquez, V., Pérez-Parallé, M.L., Sánchez, J.L., Abad, M., 2005. Differences in sterol composition of clams (Ruditapes decussatus) from three rías in Galicia (NW Spain). Mar. Biol. 147, 663-670.

Pérez Camacho, A., Delgado, M., Fernández-Reiriz, M.J., Labarta, U., 2003. Energy balance, gonad development and biochemical composition in the clam Ruditapes decussatus. Mar. Ecol. Prog. Ser. 258, 133-145.

Picado, A., Dias, J.M., Fortunato, A., 2009. Effect of flooding the salt pans in the Ria de Aveiro. J. Coastal Res. 56,1395-1399.

Robert, R., Trut, G., Laborde, J.L., 1993. Growth, reproduction and gross biochemical composition of the Manila clam Ruditapes philippinarum in the Bay of Arcachon, France. Mar. Biol. 116, 291-299.

Rodríguez, S., Quintana, R., Lamas, L., Ayensa, G., Velasco, F.J., Pascual, C., 1993. Etúde comparative du cycle gamétogénique et composition biochímique de Tapes decussatus et Ruditapes philippinarum dans la Ría de Muros y Noya. In: Bernabe G., Kestemont P. (eds.) Bordeaux Aquaculture 92. Production, Environment and Quality. Special 762 Publication-European Aquaculture Society, Bordeaux, pp 503- 511.

Sastry, A.N., 1979. Pelecypoda (excluding Ostreidae). In: Giese A.C., Pearse J.S. (eds.) Reproduction of marine invertebrates, Vol 5. Molluscs: Pelecypods and lesser classes, Academic Press, New York, pp 113-292.

Seed, R.,1976. Ecology. In Bayne B.L. (eds.), Marine mussels: Their ecology and Physiology, Cambridge University Press: 13-65.

Serdar, S., Lök, A., 2009. Gametogenic cycle and biochemical composition of the transplanted carpet shell clam Tapes decussatus, Linnaeus 1758 in Sufa (Homa) Lagoon, Izmir, Turkey. Aquaculture 293, 81-88.

Shafee, M.S., Daoudi, M., 1991. Gametogenesis and spawning in the carpet-shell clam, Ruditapes decussatus (L.) (Mollusca: Bivalvia), from the Atlantic coast of Morocco. Aquacult. Fish. Manage. 22, 203-216. 
Shakir, F.K., Audilet, D., Drake, III A.J., Shakir, M.M., 1994. A rapid protein determination by modification of the Lowry Procedure. Anal. Biochem. 216, 232233.

Sokal, R.R., Rohlf, F.J., 1981. Biometry. Freeman W.H., Co. (ed.), San Francisco, 859 pp.

Tlili, S., Métais, I., Ayache, N., Boussetta, H., Mouneyrac, C., 2012. Is the reproduction of Donax trunculus affected by their sites of origin contrasted by their level of contamination? Chemosphere 84, 1362-1370.

Trigui-El-Menif, N., Le Pennec, M., Maamouri, F., 1995. Reproduction of the European Clam Ruditapes decussatus (mollusc, bivalve) along the Tunian coasts. Mar. Life 5(1), 35-42.

Urrutia M.B., Ibarrola I., Iglesias J.I.P., Navarro E., 1999. Energetics of growth and reproduction in a high-tidal population of the clam Ruditapes decussatus from Urdaibai Estuary (Basque Country, N. Spain). J. Sea Res. 42, 35-48.

Vilela, H. (1950) Vida bentónica de Tapes decussatus. Travail Station de Biologie Marine Lisbonne 53:1-79. (In portuguese).

Viles, F. J., Silverman, L. (1949) Determination of starch and cellulose with anthrone. J. Analyt. Chem. 21:950-953.

Walne, P.R., Mann, R., 1975. Growth and biochemical composition of Ostrea edulis and Crassostrea gigas. In Barnes H. (ed) Proceedings of the 9th European Marine Biology Symposium Oban (Scotlland), pp 587-607.

Xie, Q., Burnell, G.M., 1994. A comparative study of the gametogenic cycles of the clams Tapes philippinarum (Adams and Reeve 1850) and Tapes decussatus (Linnaeus) on the south coast of Ireland. J. Shellfish Res. 13 (2), 467-472. 
Figure 1 - Ria de Aveiro and Ria Formosa Lagoon location.

789

790 Figure 2 - Monthly mean values of sea surface temperature (SST) (A) and chlorophyll in

791 Ria de Aveiro and Ria Formosa Laggon from May 2010 to April 2012.

792

793 Figure 3 - Monthly variations in gonadal development of Ruditapes decussatus 794 populations from Ria de Aveiro and Ria Formosa lagoon, during May 2010 to April 795 2012. Males (top) and Females (bottom).

796

797 Figure 4 - Monthly variations in gonad index $(\mathrm{Gl})$ (mean, $\mathrm{n}=20$ ) of Ruditapes 798 decussatus populations from Ria de Aveiro and Ria Formosa Lagoon, during May 2010 to April 2012.

800

801

Figure 4 - Condition index (mean $\pm \mathrm{SD}$ ) of Ruditapes decussatus populations from Ria 802 de Aveiro and Ria Formosa lagoon, during May 2010 to April 2012. (*statistically 803 significant differences, $P<0.05$ found between populations).

804

805

806

807

808

809 
$810 \quad$ Figure 1

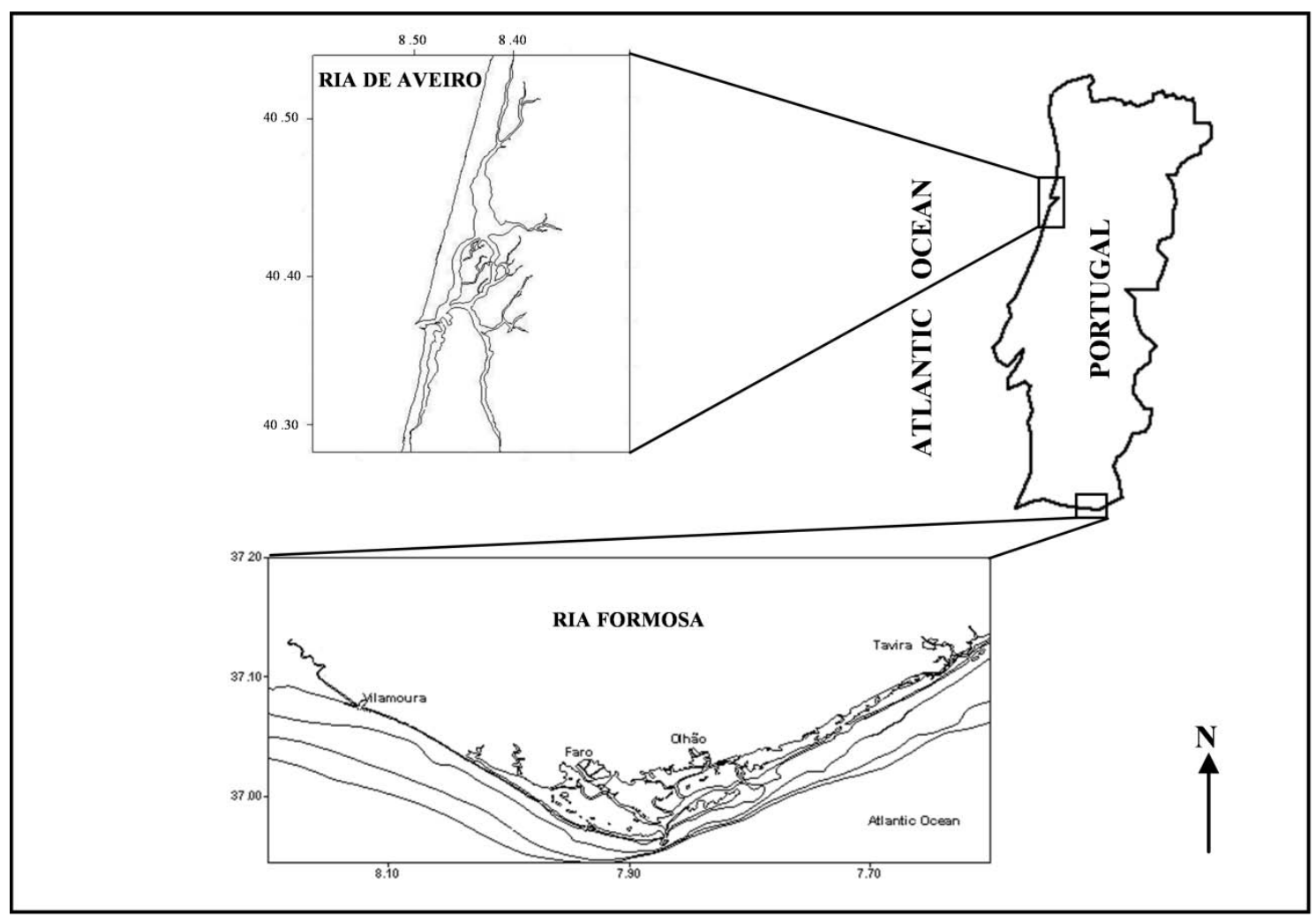

812

813

814

815

816

817

818

819

820

821

822

823

824

825 
Figure 2

827

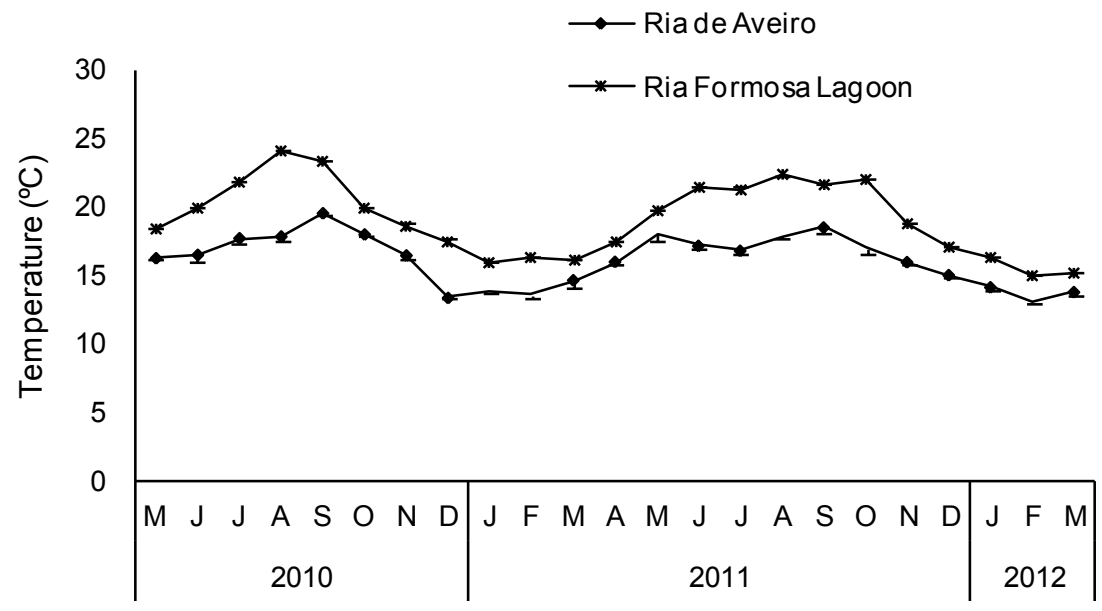

828

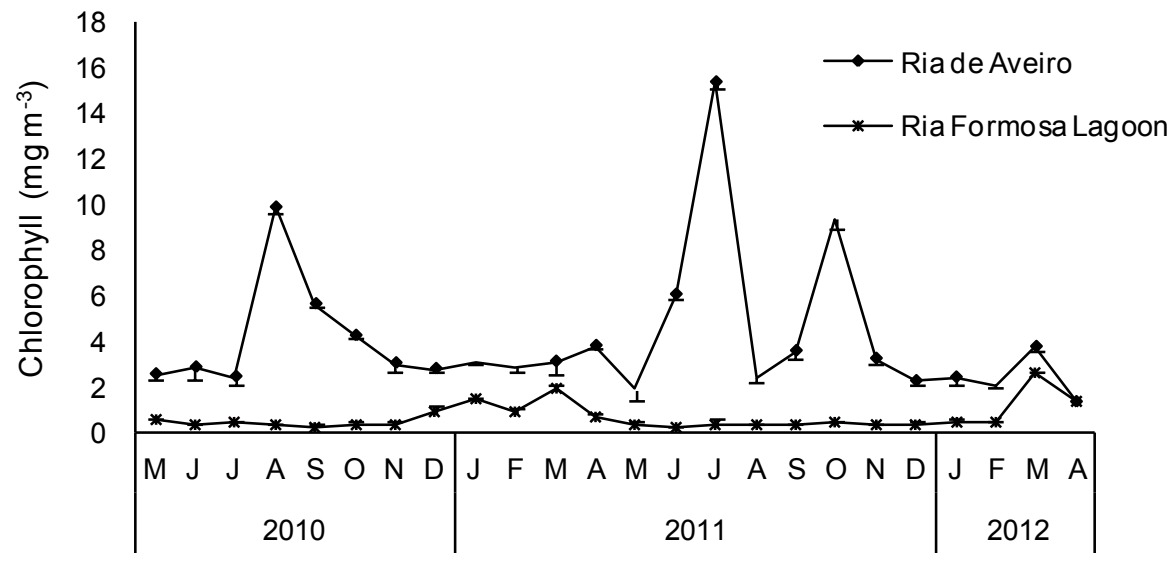

829

830

831

832

833

834 

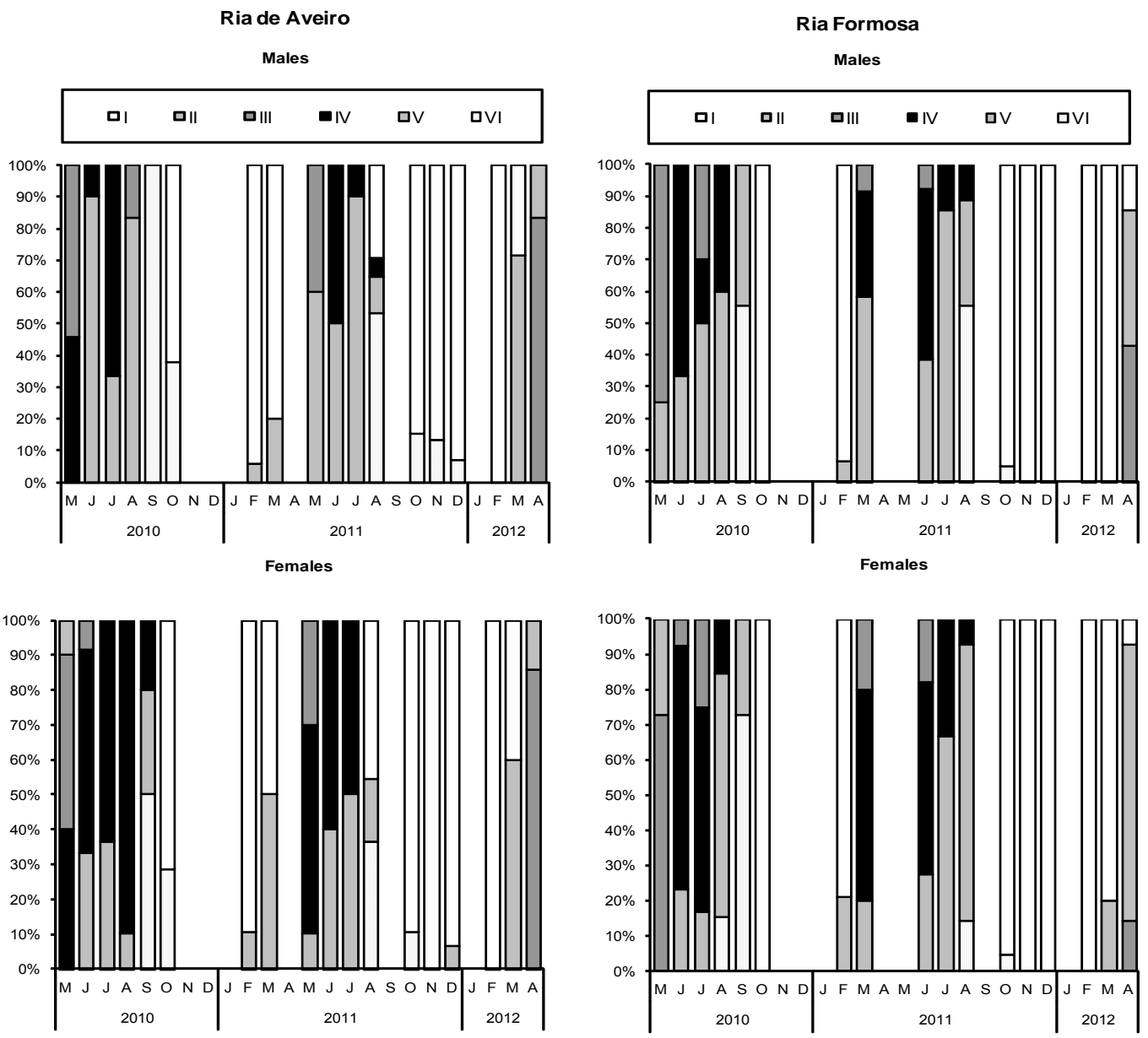

838

839

840

841

842

843

844 
$847 \quad$ Figure 4

848

849

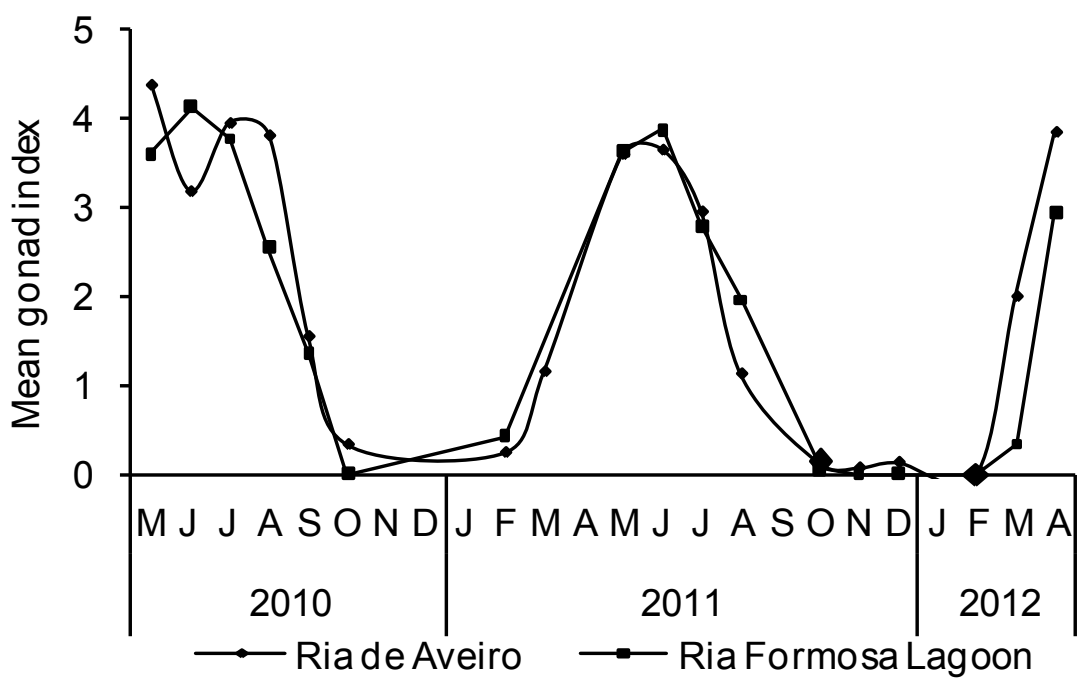

850

851

852

853

854

855

856

857

858 
$861 \quad$ Figure 5

862

863

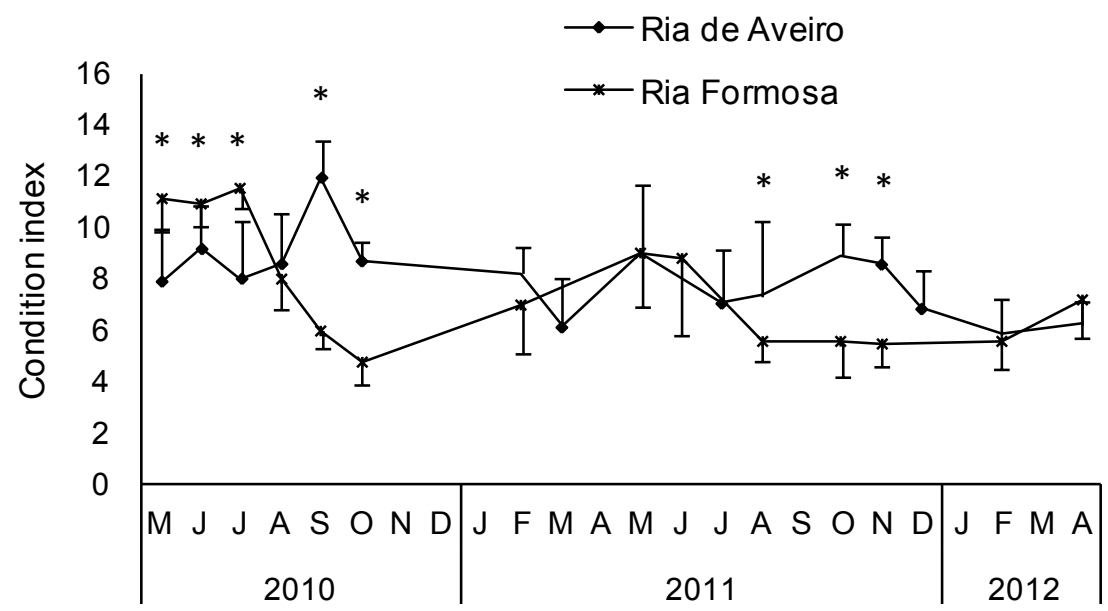

864

865

866

867

868

869

870

871

872

873

874 
876 Table 1 - Reproductive scale for Ruditapes decussatus adapted from Delgado and Pérez-Camacho 877 (2005).

Stage

Period of sexual rest (phase I)
Histologic description

Gonadal follicles are absent and connective and muscular tissue occupies the entire zone from the digestive gland to foot. There is no evidence of gonadal development and sex determination is not possible.

Initiation of gametogenesis (phase II)

Follicles and gonadal acini begin to appear in females and males. They increase in size, and appear covered with oocytes in the growth phase in the females and with immature gametes (spermatogonia and spermatocytes) in the males.

Advanced gametogenesis (phase III)

Ripe (phase IV)

Partially spawned (phase V)

Spent (phase VI)
The gametes are discharged. Depending on the degree of spawning the follicles are more or less empty. The follicle walls are bro-ken. There are many empty spaces between and within the follicles.

The follicles occupy a large part of the visceral mass. The presence of muscular and connective tissue is reduced. At the end of this stage, characterised by intense cellular growth in females, the oocyte protrudes from the centre of the lumen, remaining attached to the wall via the peduncle. The abundance of free oocytes equals those attached to the wall of the follicle. In males, majority of the acini were full of spermatids and

Corresponding to the maturity of the majority of gametes. In the mature oocytes the rupture of the peduncle occurs, and the oocytes consequently occupy the follicular interior. In males, the gonadal acini mainly contain spermatozoids.

Abundant interfollicular connective tissue. Occasional residual sperm or oocytes resent. 
Table 2 - Results of Pearson correlation between studied parameters ( $r$, correlation coefficient, $P, P$ value, n.c., no correlation was found).

\begin{tabular}{|c|c|c|c|c|c|c|c|c|c|c|c|c|c|c|}
\hline & \multicolumn{7}{|c|}{ Ria de Aveiro } & \multicolumn{7}{|c|}{ Ria Formosa Lagoon } \\
\hline & $\begin{array}{c}\text { Temperature } \\
\text { (SST) }\end{array}$ & $\begin{array}{c}\text { Gonadal } \\
\text { index }(G \mathrm{I})\end{array}$ & $\begin{array}{l}\text { Condition } \\
\text { index }(\mathrm{Cl})\end{array}$ & Proteins & $\begin{array}{l}\text { Total } \\
\text { lipids }\end{array}$ & Glycogen & $\begin{array}{c}\text { Total } \\
\text { energy }\end{array}$ & $\begin{array}{c}\text { Temperature } \\
\text { (SST) }\end{array}$ & $\begin{array}{c}\text { Gonadal } \\
\text { index (GI) }\end{array}$ & $\begin{array}{l}\text { Condition } \\
\text { index }(\mathrm{Cl})\end{array}$ & Proteins & $\begin{array}{l}\text { Total } \\
\text { lipids }\end{array}$ & Glycogen & $\begin{array}{c}\text { Total } \\
\text { energy }\end{array}$ \\
\hline Chlorophyll & n.c. & n.c. & n.c. & n.c. & n.c. & n.c. & n.c. & n.c. & n.c. & n.c. & n.c. & n.c. & n.c. & n.c. \\
\hline Temperature (SST) & & n.c. & $\begin{array}{c}r=0.55 \\
P<0.001\end{array}$ & n.c. & n.c. & n.c. & n.c. & & n.c. & n.c. & n.c. & n.c. & n.c. & n.c. \\
\hline Gonadal index (GI) & & & n.c. & n.c. & n.c. & n.c. & n.c. & & & $\begin{array}{c}r=0.87 \\
P<0.001\end{array}$ & n.c. & n.c. & $\begin{array}{l}r=0.60 \\
P=0.01\end{array}$ & n.c. \\
\hline Condition index $(\mathrm{Cl})$ & & & & n.c. & n.c. & n.c. & n.c. & & & & n.c. & n.c. & $\begin{aligned} r & =0.78 \\
P & <0.001\end{aligned}$ & n.c. \\
\hline Proteins & & & & & $\begin{array}{l}r=-0.52 \\
P<0.01\end{array}$ & n.c. & $\begin{array}{c}r=0.87 \\
P<0.001\end{array}$ & & & & & n.c. & n.c. & $\begin{array}{c}r=0.91 \\
P<0.001\end{array}$ \\
\hline Total lipids & & & & & & n.c. & n.c. & & & & & & n.c. & n.c. \\
\hline Glycogen & & & & & & & n.c. & & & & & & & n.c. \\
\hline
\end{tabular}

884 
895

896

897

898

899 
901 Table 3 - Mean values ( \pm sd) of proteins, glycogen, total lipids ( $\mu \mathrm{g} \mathrm{mg}^{-1}$ AFDW) and total energy ( $\mathrm{KJ} \mathrm{g}^{-1}$ AFDW) of Ruditapes decussatus during the experimental period.

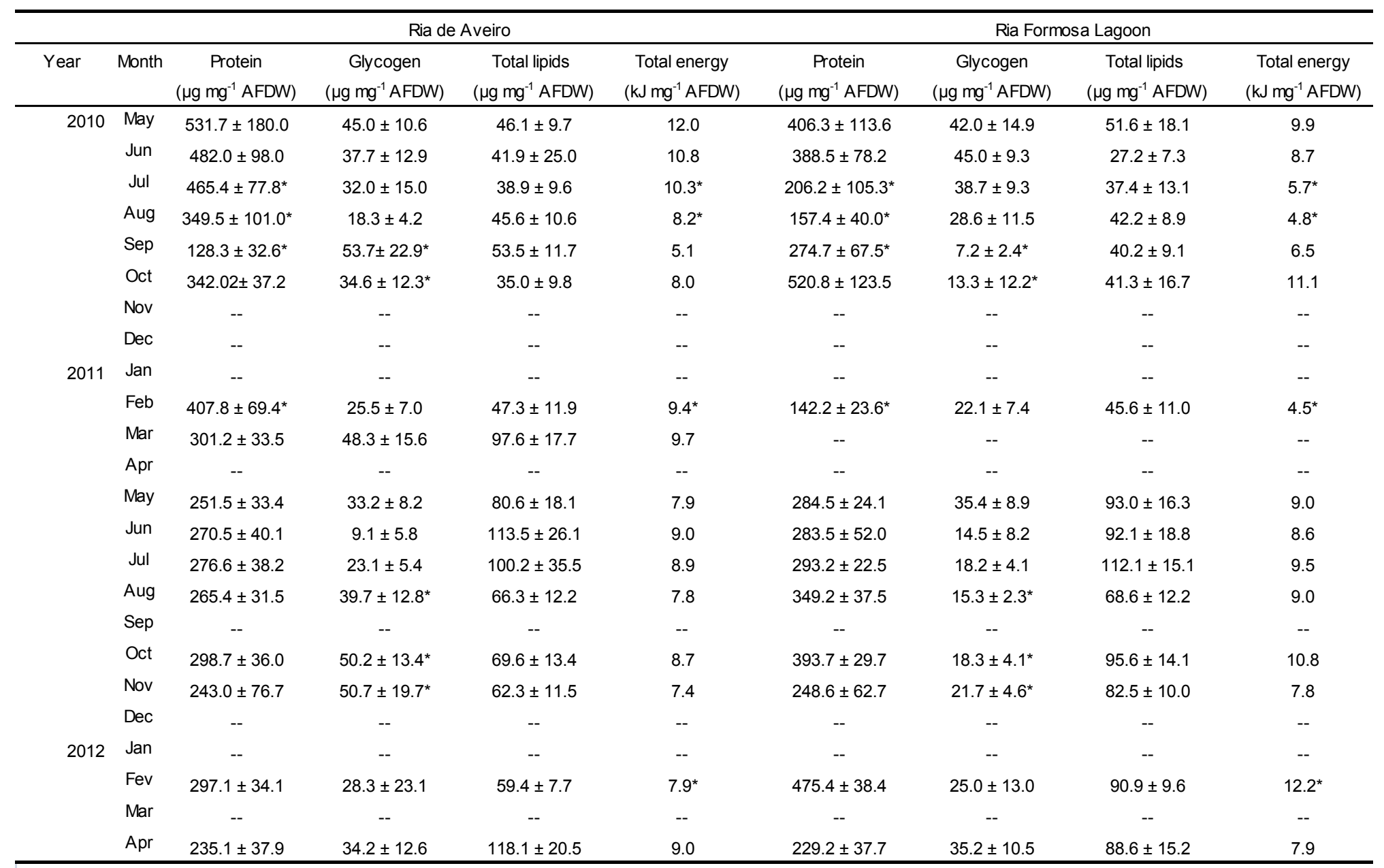

